University of Nebraska - Lincoln

DigitalCommons@University of Nebraska - Lincoln

$11-26-2008$

\title{
Comparison of three models for predicting gross primary production across and within forested ecoregions in the contiguous United States
}

\author{
Nicholas C. Coops \\ University of British Columbia \\ Colin J. Ferster \\ University of British Columbia \\ Richard H. Waring \\ Oregon State University \\ Joanne Nightingale \\ NASA Goddard Space Flight Center
}

Follow this and additional works at: https://digitalcommons.unl.edu/nasapub

Part of the Physical Sciences and Mathematics Commons

Coops, Nicholas C.; Ferster, Colin J.; Waring, Richard H.; and Nightingale, Joanne, "Comparison of three models for predicting gross primary production across and within forested ecoregions in the contiguous United States" (2008). NASA Publications. 17.

https://digitalcommons.unl.edu/nasapub/17

This Article is brought to you for free and open access by the National Aeronautics and Space Administration at DigitalCommons@University of Nebraska - Lincoln. It has been accepted for inclusion in NASA Publications by an authorized administrator of DigitalCommons@University of Nebraska - Lincoln. 


\title{
Comparison of three models for predicting gross primary production across and within forested ecoregions in the contiguous United States
}

\author{
Nicholas C. Coops ${ }^{\mathrm{a}, *}$, Colin J. Ferster ${ }^{\mathrm{a}}$, Richard H. Waring ${ }^{\mathrm{b}}$, Joanne Nightingale ${ }^{\mathrm{c}}$ \\ a Department of Forest Resource Management, 2424 Main Mall, University of British Columbia, Vancouver, Canada V6T 124 \\ ${ }^{b}$ College of Forestry, Oregon State University, Corvallis Oregon, 97331, USA \\ c NASA Goddard Space Flight Center, Terrestrial Information Systems Branch, Mail Code 614.5, Bldg 32, Greenbelt, MD 20771, USA
}

\section{A R T I C L E I N F O}

\section{Article history:}

Received 25 July 2008

Received in revised form 24 November 2008

Accepted 26 November 2008

\section{Keywords:}

Gross primary production

Modeling

MODIS

SPOT

3PG

\begin{abstract}
A B S T R A C T
Gross primary production (GPP), the photosynthetic uptake of carbon, is an important variable in the global carbon cycle. Although continuous measurements of GPP are being collected from a network of micrometeorological towers, each site represents a small area with records available for only a limited period. As a result, GPP is commonly modeled over forested landscapes as a function of climatic and soil variables, often supplemented with satellite-derived estimates of the vegetation's light-absorbing properties. Since the late 1990s, a number of models have been developed to provide seasonal and annual estimates of GPP across much of the Earth. Each model, however, contains different underlying assumptions and requires different amounts of data. As a result, predictions vary, sometimes significantly. In this paper we compare modeled estimates of GPP for forested areas across the U.S.A. derived from: NASA's MODIS Product (MOD17); the C-Fix model using SPOT-VGT satellite-derived vegetation data; and the Physiological Principles Predicting Growth from Satellites (3-PGS) model, a process-based model that requires information on both climate and soil properties. The models predicted average ecoregion values of forest GPP between 9.8 and $14.1 \mathrm{MgC} \mathrm{ha}^{-1} \mathrm{y}^{-1}$ across the United States. 3-PGS predicted the lowest values while the C-Fix model, which included a $\mathrm{CO}_{2}$ fertilization factor, produced the highest estimates. In the western part of the country, estimates of GPP within a given ecoregion varied by as much as $50 \%$, whereas in the northeast, where topography and climate are less extreme, variation in GPP was less than 10\%. Within ecoregions, 3PGS predicted the most variation, reflecting its sensitivity to variation in soil properties. We conclude that where model predictions disagree, an opportunity is presented to evaluate underlying assumptions through sensitivity analyses, additional data collection and where more detailed study is warranted.
\end{abstract}

(c) 2008 Elsevier Inc. All rights reserved.

\section{Introduction}

Over the last decade, a network of sites where $\mathrm{CO}_{2}$ exchange is continually measured from towers has expanded to more than 200 locations. To extrapolate predictions of carbon exchange from information acquired at these tower sites, it is necessary to take into account spatial variation in vegetation and climatic conditions. To do this requires a major effort to quantify climatic variation spatially, and to keep track of changes in the state of vegetation. Remote sensing has played a key role in providing information on both current climatic conditions and the changing state of vegetation.

Development of process-based ecosystem models has played a complementary role by utilizing remotely sensed data sets to predict seasonal and interannual variation in carbon uptake, allocation, and release back into the atmosphere over broad areas (see reviews by Landsberg, 2003; Nightingale et al., 2004). These models differ in their assumptions of how the basic processes respond to the environment

\footnotetext{
* Corresponding author. Tel.: +1 604822 6452; fax: +1 6048229106 .

E-mail address: nicholas.coops@ubc.ca (N.C. Coops).
}

and interact. As a result, the predictions of net primary production (NPP) and net carbon exchange (NEP) differ. The least difference among models is in their prediction of gross photosynthesis, termed gross primary production (GPP), because this process is the first calculated and the best understood. On average, about half of GPP is incorporated into plant tissue (Waring et al., 1998), although not all models incorporate this assumption.

The upper limit on GPP in all process models is set by the amount of light (photosynthetically active radiation) absorbed by foliage (APAR), leaf photosynthetic capacity $(\alpha)$, and the $\mathrm{CO}_{2}$ concentration of the air $\left(c_{\mathrm{a}}\right)$. The photosynthetic capacity can be assumed to be a fixed value for a particular type of vegetation or allowed to vary with soil type. Additional constraints on GPP are imposed with variation in temperature and the atmospheric humidity deficit. If models include the effects of drought on GPP, they require additional information on soils to calculate a water balance. One might assume that the most accurate model would be one that required the most information, but if the information is in error, accuracy could be less than projections made from simpler models. Even when provided the same variables, the predicted response of GPP may differ among models due to 
Table 1

Data requirements for the three models used to derive estimates of GPP across the U.S.A

\begin{tabular}{|c|c|c|c|c|c|}
\hline \multirow{4}{*}{ 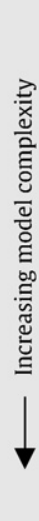 } & Model & Satellite data & Climate data & $\begin{array}{l}\text { Light-use } \\
\text { efficiency }\end{array}$ & Soils data \\
\hline & MODIS GPP & MODIS fPAR & $\begin{array}{l}\text { - Temperature } \\
\text { - Radiation } \\
\text { - VPD }\end{array}$ & $\begin{array}{l}\text { Biome } \\
\text { defined } \\
\text { maximum } \\
\alpha\end{array}$ & \\
\hline & SPOT GPP & $\begin{array}{l}f \text { PAR derived } \\
\text { from SPOT } \\
\text { and NOAA } \\
\text { AVHRR NDVI } \\
\text { data }\end{array}$ & $\begin{array}{l}\text { - } \text { Temperature } \\
\text { dependency factor } \\
\text { - } \text { Radiation } \\
\text { - Rising } \mathrm{CO}_{2} \text { effect }\end{array}$ & $\begin{array}{l}\alpha \text { fixed for all } \\
\text { vegetation } \\
\text { types }\end{array}$ & \\
\hline & 3-PGS & MODIS fPAR & $\begin{array}{l}\text { - Temperature } \\
\text { - Radiation } \\
\text { - } \mathrm{D} \\
\text { - Frost } \\
\text { - Precipitation }\end{array}$ & $\begin{array}{l}\alpha \text { function of } \\
\text { soil nitrogen } \\
\text { content }\end{array}$ & $\begin{array}{l}\text { Water } \\
\text { holding } \\
\text { capacity }\end{array}$ \\
\hline
\end{tabular}

different assumptions and the time frame over which a process is integrated.

In previously published research, we compared estimates of forest GPP for nine, broadly classified areas across the United States with three, increasingly more data-demanding models (Nightingale et al., 2008). In this paper, we extend the modeling analyses to compare the mean and spatial variation of GPP over a 5 year period within and among 84 defined ecoregions. We strive in this more detailed comparison to identify ecoregions where model predictions of GPP either closely match one another or widely differ. Agreement among models should indicate homogeneous ecoregions with similar environments, whereas disagreement would suggest heterogeneous environments for which limitations in modeling assumptions or data requirements are expressed. Where differences among model predictions are great, more in-depth analyses are warranted.

\section{Modeling GPP}

The three models compared in this paper are identified in Table 1, along with their data requirements. The simplest of the models is one devised to generate the 8-day MODIS GPP product (Running et al., 2004). In this model the maximum value of $\alpha$ is dependent on vegetation type (as defined by the MODIS land cover classification) and is reduced by two multipliers, sub-optimal temperature and vapor pressure deficits (D), both of which vary from 1 (no constraint on gas exchange) and 0 , (complete constraint on gas exchange). No attempt is made to calculate a soil water balance (Heinsch et al., 2006).

The SPOT GPP dataset is produced at 10-day intervals, based on the C-Fix model of Veroustraete et al. (2004). It differs from the other models by imposing limits of GPP when the temperature or vapor pressure is higher or lower, than an optimum value specified for a given climate (Mc Cree, 1972; Sabbe \& Veroustraete, 2000). The model also presumes a $15 \%$ enhancement of photosynthesis since the start of the industrial revolution (Veroustraete et al., 2002).

The most data-demanding model is 3-PGS (Physiological Principles Predicting Growth from Satellites), (Coops et al., 1998), although it runs at monthly time-steps. It is similar to the previously described models in using APAR and photosynthetic capacity but requires additional climatic data (frost days and precipitation) as well as estimates of soil water holding capacity and fertility to predict GPP.

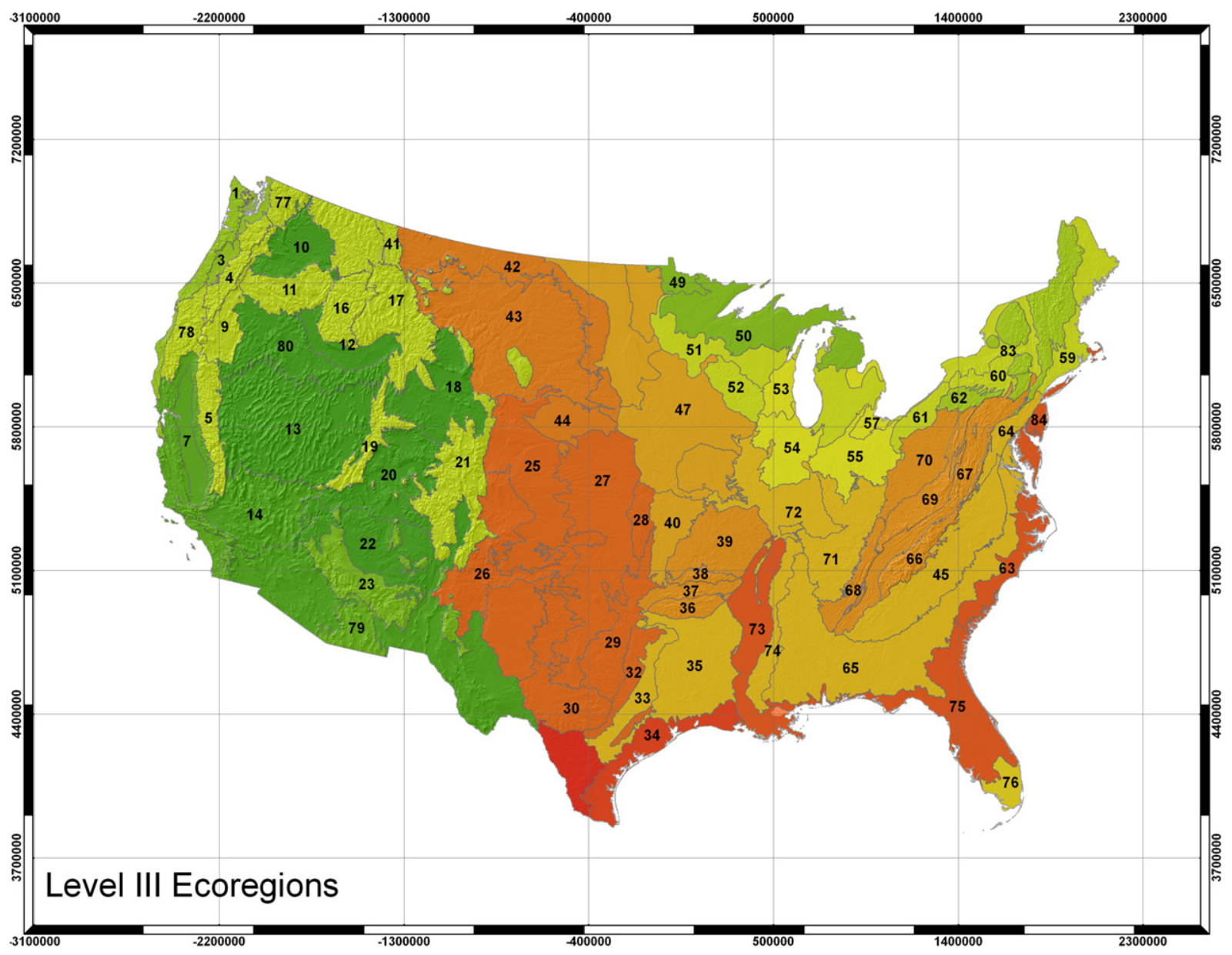

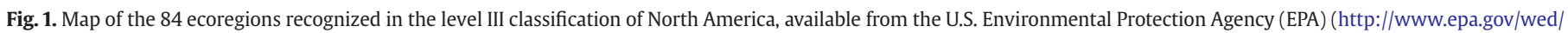
pages/ecoregions.htm). Ecoregions are recognized as areas with commonality in physiography, vegetation, and climate (CEC, 1997). 


\section{Data and methods}

\subsection{MODIS GPP}

The MODIS GPP model requires data from three sources. Biomespecific parameters such as $\alpha$, are assigned based on an 8 class, $1 \mathrm{~km}-$ pixel MODIS land cover classification and an associated Biome Parameter Look Up Table (BPLUT) (Hansen et al., 2000; Running et al., 2004). Incoming radiation is obtained, along with air temperature and relative humidity, from global scale meteorology $\left(1.00^{\circ} \times 1.25^{\circ}\right)$ via the NASA-Goddard Space Flight Centre (GFSC) Global Modeling and Assimilation Office (GMAO) GEOS-4 global climate model (DAO, 2002). There is an implicit assumption that the coarse resolution meteorological data provides a reasonably accurate depiction of surface boundary layer conditions and that these conditions are homogeneous within the spatial extent of each cell (Gebremichael \& Barroos, 2006). To estimate APAR, a third dataset is required to provide a measure of the daily fraction of photosynthetically active radiation absorbed by vegetation (fPAR). This variable comes directly from a structurally-defined land cover map and atmospherically corrected surface reflectances at a spatial resolution of $1 \mathrm{~km}$ resolution taking into account information derived from the MODIS satellite on viewing and illumination angles (Myneni et al., 2002). GPP data were provided from the Numerical Terradynamics Simulation Group (http://www.ntsg.umt.edu/) at the University of Montana MODIS at 1-km resolution for the U.S. over a five-year period (January 2000-December 2004) from the MOD-17, version 4.5, 8 -day collection. Annual GPP values were derived by summing values for 8-day periods each year and then averaging these over the fiveyear period.

\subsection{SPOT GPP}

GPP as predicted by the SPOT (C-Fix) model is based on a fixed conversion of absorbed PAR (1.1 $\mathrm{gC} \mathrm{MJ}^{-1}$ APAR) and requires information on: PPAR, derived from SPOT and the National Oceanic and Atmospheric Administration (NOAA) Advanced Very High Resolution Radiometer (AVHRR), daily incoming solar radiation and temperature data (Sabbe \& Veroustraete, 2000). The model also predicts autotrophic (and heterotrophic) respiration to allow explicit calculation of NPP. 10-day integrated global SPOT NPP surfaces were acquired for the five-year period (January 2000-December 2004) (http://geofront.vgt.vito.be/geosuccess/). To convert the available NPP surfaces to GPP for this comparison a simple linear function of mean daily temperature is used to calculate respiration $\left(R_{a}\right)$ (Veroustraete et al., 2002) and when added to estimates to NPP yields GPP, following the approach of Nightingale et al. (2008). Annual averaged GPP was calculated by summing values for each 10-day period through sequential years.

\subsection{3-PGS GPP}

Coops et al. (1998) developed a satellite-driven version of 3-PG (Landsberg \& Waring, 1997) so that estimates of fPAR could be obtained without modeling seasonal allocation and turnover of carbon in leaves. The model contains a number of simplifying assumptions that have emerged from studies conducted over a wide range of forests (Landsberg et al., 2003). These include:

- Climatic data can be summarized at monthly intervals with little loss in accuracy.

- Each month, the most limiting climatic variable on photosynthesis is selected, based on departure from conditions that are optimum (expressed as unity) or completely limited (expressed as zero).

- Maximum canopy stomatal conductance approaches a plateau above a leaf area index (LAI) of 3.0.
- Net primary production and autotrophic respiration are comparable fractions of gross photosynthesis (Waring et al., 1998).

- The ratio of actual/potential photosynthesis decrease in proportion to the reductions in the most limiting environmental factor.

- The lower the ratio of actual/potential photosynthesis, the higher the proportion of photosynthate allocated below ground.

We ran 3-PGS with the same fPAR and climate data as provided for MODIS model. Additional precipitation data required by 3-PGS were obtained using the Parameter-elevation Regressions on Independent Slopes Model (PRISM) available from Oregon State University (http:// www.prismclimate.org).

Photosynthetic capacity $(\alpha)$ was assumed to vary from 1.0 to $3.0 \mathrm{~g} \mathrm{C}$ $\mathrm{MJ}^{-1}$ APAR as a non-linear function of soil nitrogen content, which ranged from 250 to $2000 \mathrm{gN} \mathrm{m}^{-3}$ across the U.S, based on cluster analysis of STATSGO soil parameters (Hargrove \& Hoffman, 2004). The

Table 2

List of level III EPA ecoregions displayed in Fig. 1

\begin{tabular}{|c|c|c|c|}
\hline $\begin{array}{l}\text { Ecoregion } \\
\text { number }\end{array}$ & & $\begin{array}{l}\text { Ecoregion } \\
\text { number }\end{array}$ & Name \\
\hline 1 & Coast Range & 43 & Northwestern Great Plains \\
\hline 2 & Puget Lowland & 44 & Nebraska Sand Hills \\
\hline 3 & Willamette Valley & 45 & Piedmont \\
\hline 4 & Cascades & 46 & Northern Glaciated Plains \\
\hline 5 & Sierra Nevada & 47 & Western Corn Belt Plains \\
\hline 6 & $\begin{array}{l}\text { Southern and Central California } \\
\text { Chaparral and Oak Woodlands }\end{array}$ & 48 & Lake Agassiz Plain \\
\hline 7 & Central California Valley & 49 & $\begin{array}{l}\text { Northern Minnesota } \\
\text { Wetlands }\end{array}$ \\
\hline 8 & Southern California Mountains & 50 & Northern Lakes and Forests \\
\hline 9 & $\begin{array}{l}\text { Eastern Cascades Slopes and } \\
\text { Foothills }\end{array}$ & 51 & $\begin{array}{l}\text { North Central Hardwood } \\
\text { Forests }\end{array}$ \\
\hline 10 & Columbia Plateau & 52 & Driftless Area \\
\hline 11 & Blue Mountains & 53 & $\begin{array}{l}\text { Southeastern Wisconsin Till } \\
\text { Plains }\end{array}$ \\
\hline 12 & Snake River Plain & 54 & Central Corn Belt Plains \\
\hline 13 & Central Basin and Range & 55 & Eastern Corn Belt Plains \\
\hline 14 & Mojave Basin and Range & 56 & $\begin{array}{l}\text { Southern Michigan/Northern } \\
\text { Indiana Drift Plains }\end{array}$ \\
\hline 15 & Northern Rockies & 57 & Huron/Erie Lake Plains \\
\hline 16 & Idaho Batholith & 58 & Northeastern Highlands \\
\hline 17 & Middle Rockies & 59 & Northeastern Coastal Zone \\
\hline 18 & Wyoming Basin & 60 & $\begin{array}{l}\text { Northern Appalachian } \\
\text { Plateau and Uplands }\end{array}$ \\
\hline 19 & Wasatch and Uinta Mountains & 61 & Erie Drift Plain \\
\hline 20 & Colorado Plateaus & 62 & North Central Appalachians \\
\hline 21 & Southern Rockies & 63 & Middle Atlantic Coastal Plain \\
\hline 22 & Arizona/New Mexico Plateau & 64 & Northern Piedmont \\
\hline 23 & $\begin{array}{l}\text { Arizona/New Mexico } \\
\text { Mountains }\end{array}$ & 65 & Southeastern Plains \\
\hline 24 & Chihuahuan Deserts & 66 & Blue Ridge \\
\hline 25 & High Plains & 67 & Ridge and Valley \\
\hline 26 & Southwestern Tablelands & 68 & Southwestern Appalachians \\
\hline 27 & Central Great Plains & 69 & Central Appalachians \\
\hline 28 & Flint Hills & 70 & Western Allegheny Plateau \\
\hline 29 & Cross Timbers & 71 & Interior Plateau \\
\hline 30 & Edwards Plateau & 72 & $\begin{array}{l}\text { Interior River Valleys and } \\
\text { Hills }\end{array}$ \\
\hline 31 & Southern Texas Plains & 73 & Mississippi Alluvial Plain \\
\hline 32 & Texas Blackland Prairies & 74 & $\begin{array}{l}\text { Mississippi Valley Loess } \\
\text { Plains }\end{array}$ \\
\hline 33 & East Central Texas Plains & 75 & Southern Coastal Plain \\
\hline 34 & Western Gulf Coastal Plain & 76 & $\begin{array}{l}\text { Southern Florida Coastal } \\
\text { Plain }\end{array}$ \\
\hline 35 & South Central Plains & 77 & North Cascades \\
\hline 36 & Ouachita Mountains & 78 & Klamath Mountains \\
\hline 37 & Arkansas Valley & 79 & Madrean Archipelago \\
\hline 38 & Boston Mountains & 80 & Northern Basin and Range \\
\hline 39 & Ozark Highlands & 81 & Sonoran Basin and Range \\
\hline 40 & Central Irregular Plains & 82 & Laurentian Plains and Hills \\
\hline 41 & Canadian Rockies & 83 & $\begin{array}{l}\text { Eastern Great Lakes and } \\
\text { Hudson Lowlands }\end{array}$ \\
\hline 42 & Northwestern Glaciated Plains & 84 & Atlantic Coastal Pine Barrens \\
\hline
\end{tabular}


Table 3

t-test comparisons of global means of 84 ecoregion-wide values of forest GPP (upper entries)

\begin{tabular}{|c|c|c|c|c|c|}
\hline \multirow[t]{2}{*}{ Country wide } & \multirow{2}{*}{$\frac{\text { Mean } 1}{\text { MgC ha }{ }^{-1} \mathrm{y}^{-1}}$} & Mean 2 & \multirow[t]{2}{*}{$t$-value } & \multirow[t]{2}{*}{$p$} & \multirow[t]{2}{*}{$N$} \\
\hline & & $\overline{\mathrm{MgC} \mathrm{ha}}{ }^{-1} \mathrm{y}^{-1}$ & & & \\
\hline MODIS vs SPOT & 9.9 & 14.1 & -6.6 & $0.0001^{*}$ & 84 \\
\hline MODIS vs 3PGS & 9.9 & 9.8 & 0.2 & 0.810 & 84 \\
\hline SPOT vs 3PGS & 14.1 & 9.8 & 5.8 & $0.0001^{*}$ & 84 \\
\hline \multirow[t]{2}{*}{ Among ecoregions } & Std. dev. 1 & Std. dev. 2 & \multirow[t]{2}{*}{$F$-ratio variances } & \multirow[t]{2}{*}{$p$ variances } & \multirow[t]{2}{*}{$N$} \\
\hline & $\overline{\operatorname{MgC~ha}{ }^{-1} \mathrm{y}^{-1}}$ & $\overline{\operatorname{MgC~ha}^{-1} \mathrm{y}^{-1}}$ & & & \\
\hline MODIS vs SPOT & 3.6 & 4.6 & 1.7 & $0.017^{*}$ & 84 \\
\hline MODIS vs 3PGS & 3.6 & 5.1 & 2.1 & $0.001^{*}$ & 84 \\
\hline SPOT vs 3PGS & 4.6 & 5.1 & 1.2 & 0.364 & 84 \\
\hline
\end{tabular}

Significant differences $(p<0.05)$ are denoted with an asterisk, based on a 2-sided $t$-test and variation in GPP among all forested ecoregions (lower entries) are compared with an $F$-test.

same type of cluster analysis provided an estimate of available water storage capacity in the surface $1.5 \mathrm{~m}$ of soil (details of both of these procedures are found in Nightingale et al., 2007, 2008). Constraints on photosynthesis in 3-PGS are imposed in a way similar to the other models, but with additional limitations from frost and soil drought.

\subsection{Regional classification of vegetation}

Forested areas across the U.S were first defined using the MODISderived UMD (University of Maryland) land cover classification scheme. We stratified the classification further into 84 ecoregions, recognized as areas with some commonality in physiography, vegetation, and climate using the level III classification of North America available from the U.S. Environmental Protection Agency (EPA) (Fig. 1, and associated Table 2). (http://www.epa.gov/wed/pages/ecoregions.htm).

\subsection{Analysis}

We first compare differences in model predictions of forest GPP in reference to seasonal and interannual climatic variation, averaged for each of the 84 ecoregions. We then compare the five-year averaged annual estimate of GPP for forested cells within all ecoregions, and the variation in annual GPP across all of these ecoregions with $t$-tests, using SAS software (SAS, 2004). Finally, model estimates of GPP within the forested portions of ecoregions are compared after being normalized as a percentage of the mean value of GPP predicted for each ecoregion. The analysis includes creation of a series of color comparison to depict both absolute and relative variation in model predictions across the U.S.

\section{Results}

A comparison of the seasonal predictions of ecoregion GPP for each year of the five-year period indicates that in the winter (December through February), differences among models in GPP were small, $\leq 0.8 \mathrm{MgC} \mathrm{ha}{ }^{-1}$ month $^{-1}$. The SPOT-derived estimates were slightly higher than MODIS predictions, particularly within ecoregions 76 (Southern Florida Coastal Plain) and 34 (Western Gulf Coast Plain forests). In the year 2000, SPOT and 3PGS predictions most differed from MODIS; otherwise differences among years were modest.

During the spring (March through May), both the SPOT, and to a lesser extent the 3PGS estimates of GPP, were larger than the MODIS projections, with no clear differences among years. During the summer (June through August), the greatest differences were observed $\left(\sim 2.0 \mathrm{MgC} \mathrm{ha}{ }^{-1}\right.$ month $\left.^{-1}\right)$ in particular in the western ecoregions 1 (Coast Range) and 3 (Willamette Valley) where 3-PGS values were higher than MODIS and SPOT predictions, and in ecoregion 8 (Southern California Mountains) where 3PGS predicted less GPP than the other models. In autumn (September through
December), MODIS continued to predict lower GPP than the other models, with SPOT consistently higher than MODIS. Overall, across all seasons, the most variable ecoregions include: 78 (Klamath Mountains); 76 (Southern Florida Coastal Plain) and 7 (Central California Valley).

A $t$-test of independent samples of GPP means for the 5 years, in forested parts of all ecoregions, indicates that SPOT GPP predictions were significantly higher ( $42 \%)$ than the other two models (Table 3 ). In regard to variation in GPP among ecoregions (lower portion of Table 3), MODIS showed significantly less variation than the other models ( $p<0.05$ using an $F$-test).

Maps of GPP for the three different models are shown in Fig. 2(A)-(C). As expected, the pattern of mean five-year GPP is generally consistent for all models, with the Marine West Coast forests in the Pacific Northwest (1: Coast Range, 4: Cascades), the forests of the South-Eastern Plains (75: Southern Coastal Plain) and the Mixedwood Plains of the Eastern Temperate forests (59: Northeastern Highlands) exhibiting the highest GPP. In contrast, the evergreen forests of the Western Cordillera (7: Central California Valley), the Mediterranean California (6: Central California Chaparral and Oak Woodlands and 8: Southern California Mountains) forests and the forests of the Temperate Sierras (5: Sierra Nevada) have much lower GPP. A distinction occurs in the Mediterranean Californian forests (6: Southern and Central California Chaparral and Oak Woodlands and 8: Southern California Mountains) where 3PGS model predicts lower GPP than the MODIS model, which in turn, is less than the SPOT predictions. Similarly, in the Northern Mixedwood Shield forests, 3PGS predictions are higher than those derived from SPOT and MODIS models.

In addition to comparing mean GPP model predictions across the country, we evaluated the extent that the models defined spatial variation within ecoregions. To do this, we estimated the multiyear mean GPP for each forested pixel within an ecoregion, and compared that value in reference to the overall ecoregion mean (Fig. 2(D)-(F)). Color codes in the figure distinguish pixels with higher or lower values than the mean generated by each model for each ecoregion. It follows that locations within an ecoregion that are more productive than others due to climatic conditions should be recognized by all three models. Variation associated with mapped differences in soil properties would only be recognized by the 3PGS model. On the other hand, general agreement among all models, in the spatial distribution of below and above averaged productivity across an ecoregions, would suggests uniformity in soils and a similar climate.

The spatial variation in the MODIS GPP estimates is shown in Fig. 2D, and indicates in general, there are only a few locations where the MODIS predictions are larger than the overall ecoregion mean, as would be expected because $\alpha$ is assigned from a biome-wide look-up table. The main locations with higher than average values are found are along the coast of the Mediterranean Californian forests (6: Southern and Central California Chaparral and Oak Woodlands and 8: Southern California Mountains) and in 12: the Snake River ecoregion. Areas significantly lower than the ecoregion means include the western portions of the 60 : Northern Appalachian Plateau and Uplands, the Marine West Coast forests, and the Western Cordillera forests in the interior.

For the SPOT predictions (Fig. 2E), greater spatial variation is apparent with an increase in the number of cells that is lower or higher than the ecoregion mean. These again include pockets of higher than average GPP along the forests of the Mediterranean Californian coast, and a small island of increased GPP in the Western Cordillera forests of Central Idaho. Areas with below-average GPP compared to the ecoregion mean, include the western slopes of the Atlantic Highland forests, the Eastern Mixedwood Plains, the interior Western Cordillera forests, and the forests of Marine West coast. The $15 \% \mathrm{CO}_{2}$ fertilization effect in the SPOT model has no impact on the spatial variation in GPP; it only increases the overall mean estimate of GPP. 


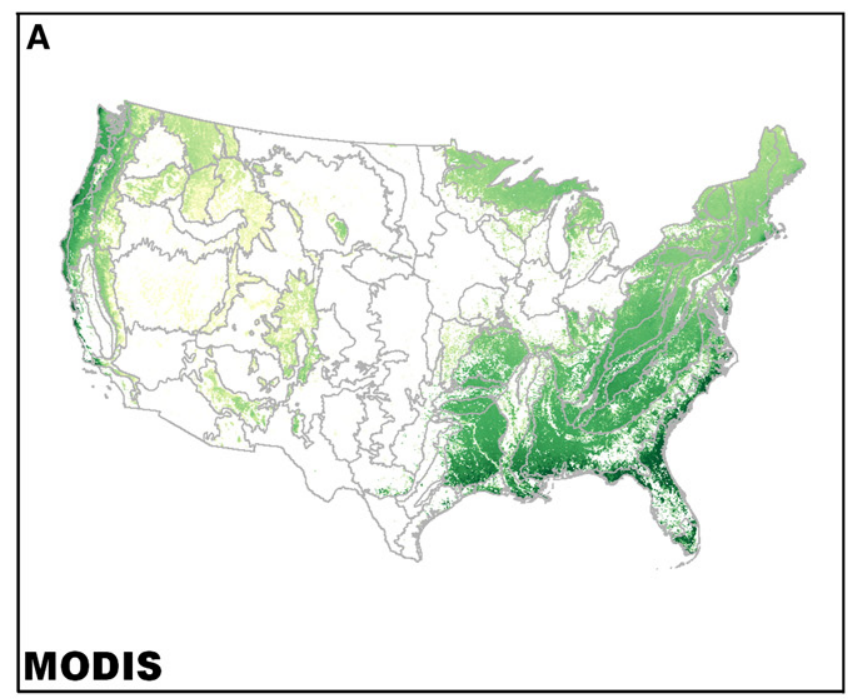

D

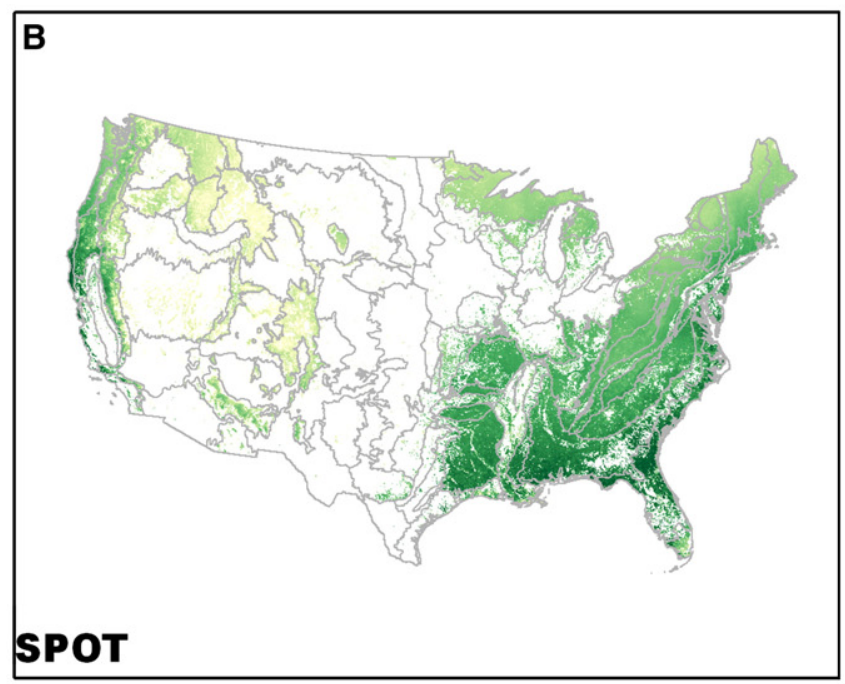

MODIS

E

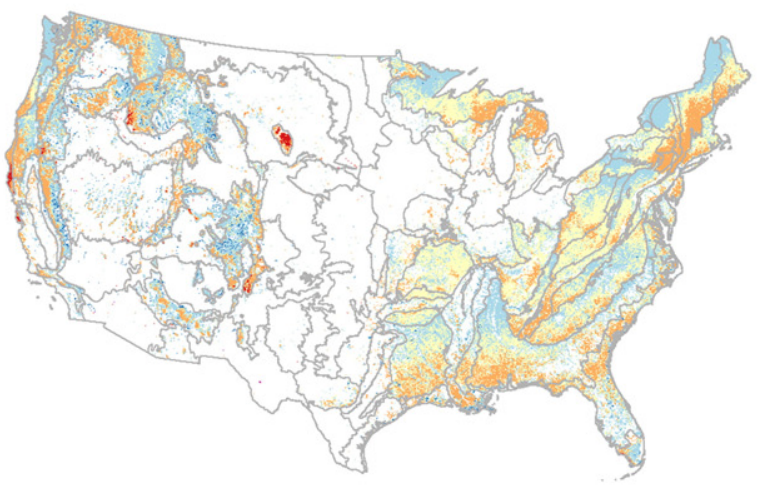

\section{SPOT}

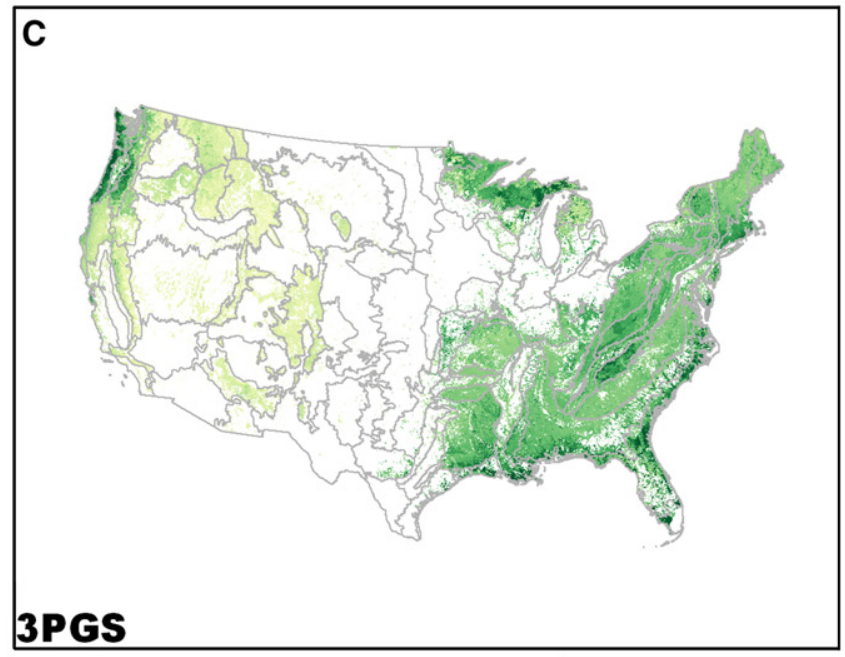

Average Annual GPP (2000 - 2005)

\begin{tabular}{l}
$28 \mathrm{MgC}$ ha-1 $\mathrm{yr}-1$ \\
0 \\
\hline
\end{tabular}

F

\section{PGS}

\begin{tabular}{|c|}
\hline \hline Variation Within Ecoregion \\
(Pixel - Ecoregion Mean)/(Ecoregion Mean) \\
$-0.89052105--0.5$ \\
\hline$-0.5--0.05$ \\
$-0.05-0.05$ \\
$0.05-0.5$ \\
$0.5-1$ \\
$>1$ \\
\hline
\end{tabular}




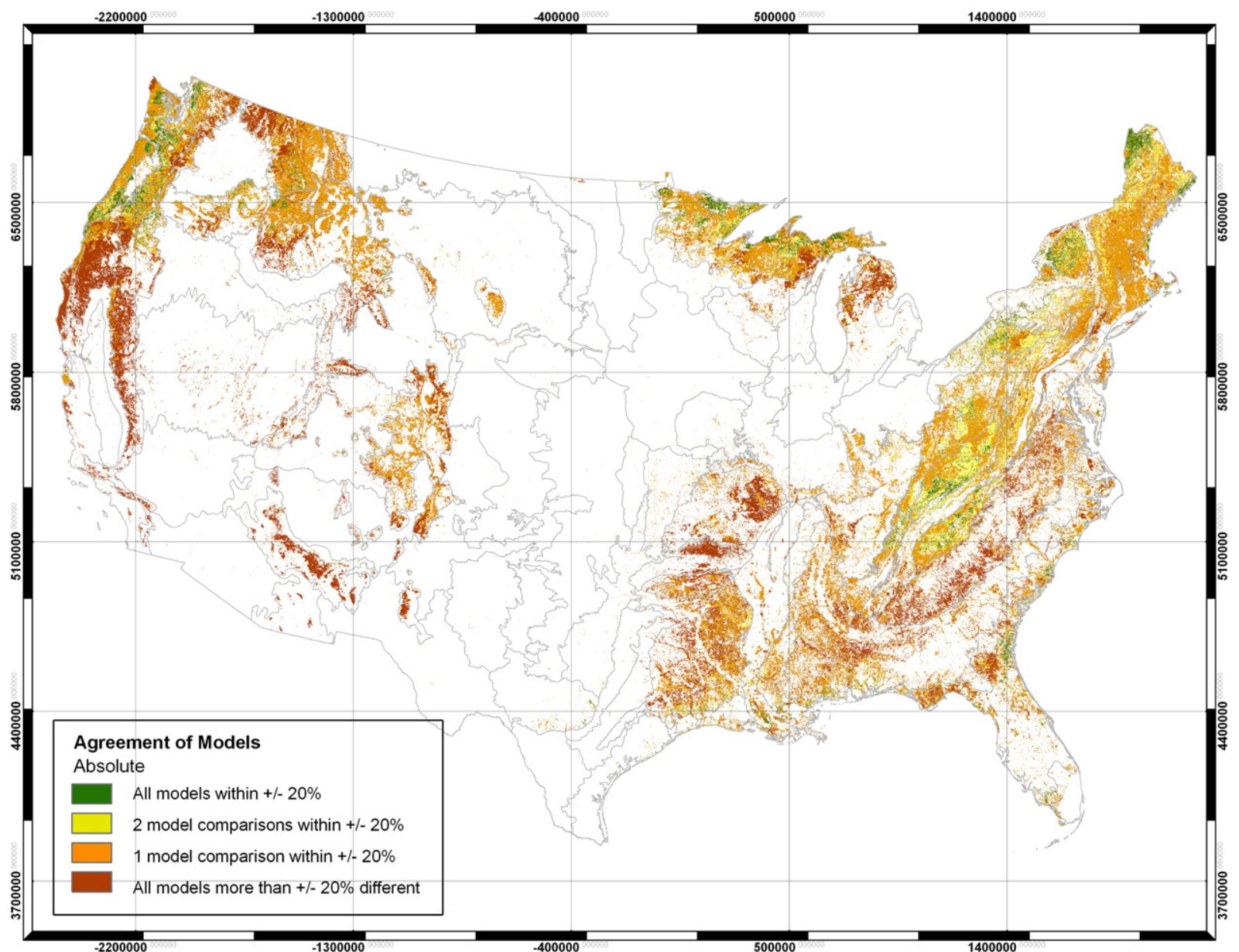

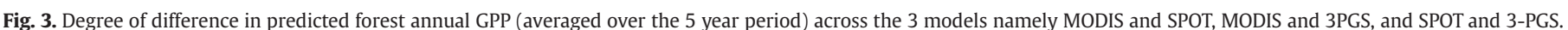

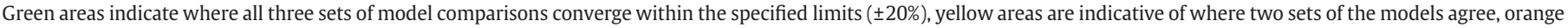
represents a single set of model agreement, and brown where none of the sets of models agreed within $20 \%$.

3PGS estimates show a markedly different spatial pattern with significantly more variation in GPP, as indicated by Fig. 2(F). Areas which have an increase in GPP relative to the ecoregion mean include forests along the Marine West coast, and in particular, the Eastern side of the Cascade and Coast Mountains, parts of the Mediterranean Californian coast forests along the western edge, areas of coastal Mississippi Alluvial (73: Mississippi Alluvial Plain, 74: Mississippi Valley Loess Plains) and Southeast Coastal Plain forest and the Ozark Quachita-Appalachian forests (63: Middle Atlantic Coastal Plain). In contrast, areas which have reduced GPP compared to their ecoregion means include the Atlantic highland forests, areas of interior Western Cordillera and the central (50: Northern Lakes and Forests) northern forests.

The general level of agreement between the three models is shown spatially in Fig. 3, with green areas indicating pixels where all model predictions agreed to within $20 \%$, yellow areas indicate where two sets of model comparisons agreed (any two of 3PGS, SPOT and MODIS), orange where only one pair of models agreed and red where none of the three models agreed to within $20 \%$. As the figure shows, in the Marine West coast of the Pacific Northwest, there is good agreement between the three GPP predictions with, in most cases, two out of three, or all three models, within $20 \%$. In particular, forests around the Willamette Valley in Oregon are in good agreement. Model differences become apparent on the eastside of Cascade mountain range, the
Northern Rockies in northern Idaho and the drier forest of the Western Cordillera in interior Oregon. In California, there is little model agreement in GPP between any set of model comparisons. Similarly, model predictions for forests in the Temperate Sierras, particularly those in the Upper Gila Mountains, are in poor agreement. In the southern part of the country, there is also large variation, with some regions showing very good agreement, and others less so. GPP estimates for forests along the Coastal Mississippi Alluvial and Southeast Coastal Plain in general are in good agreement for two or more model comparisons. In contrast, the forests in the southeastern plains show wide variation in modeled mean GPP. Along the east coast of the U.S, there again is larger variation in GPP predictions with only 1 set of models agreeing. The agreement improves in the north with the Atlantic Highland and the Mixedwood Plains forest having predicted GPP within $20 \%$.

Table 4 provides a detailed breakdown of these results, and show the mean annual forested GPP within each ecoregion, for each model, and the percent area within each ecoregion where the models agree. The shaded columns match the color breakdown in Figs. 4 and 5. The 10 most forested ecoregions (shaded darker gray) indicate that the MODIS GPP predictions were consistently the lowest, whereas the SPOT predictions were the highest, in 2 out of 3 cases (Table 3 ). The overall mean annual GPP ( $\left.\mathrm{MgC} \mathrm{ha}^{-1} \mathrm{y}^{-1}\right)$ for all ecoregions was similar 
Table 4

Mean annual forested GPP within each numbered ecoregion, for each model, and the percent forested area, within each ecoregion where the models agree

\begin{tabular}{|c|c|c|c|c|c|c|c|c|c|c|c|}
\hline \multirow[t]{2}{*}{ No. } & \multicolumn{3}{|c|}{ Mean GPP (MgC ha $\left.{ }^{-1} \mathrm{y}^{-1}\right)$} & \multicolumn{4}{|c|}{ Absolute agreement } & \multicolumn{4}{|c|}{ Spatial variation agreement } \\
\hline & MODIS & SPOT & 3PGS & $\% 3$ agree & \%2 agree & \% 1 agree & $\% 0$ agree & $\% 3$ agree & $\% 2$ agree & $\% 1$ agree & $\% 0$ agree \\
\hline 1 & 15.22 & 17.28 & 17.95 & 19 & 12 & 51 & 18 & 26 & 11 & 42 & 20 \\
\hline 2 & 12.57 & 12.43 & 10.70 & 22 & 19 & 53 & 6 & 29 & 21 & 46 & 4 \\
\hline 3 & 13.37 & 13.96 & 15.22 & 44 & 13 & 39 & 4 & 36 & 9 & 51 & 4 \\
\hline 4 & 11.77 & 14.74 & 12.84 & 18 & 18 & 40 & 24 & 28 & 13 & 55 & 4 \\
\hline 5 & 8.85 & 16.26 & 4.93 & 0 & 0 & 12 & 88 & 40 & 15 & 42 & 3 \\
\hline 6 & 12.33 & 20.52 & 5.52 & 0 & 0 & 10 & 90 & 24 & 18 & 46 & 13 \\
\hline 7 & 7.16 & 15.34 & 4.67 & 0 & 0 & 22 & 77 & 12 & 11 & 50 & 26 \\
\hline 8 & 9.58 & 19.08 & 3.69 & 0 & 0 & 3 & 97 & 34 & 18 & 38 & 10 \\
\hline 9 & 8.74 & 12.24 & 6.23 & 9 & 7 & 40 & 45 & 12 & 12 & 62 & 14 \\
\hline 10 & 5.19 & 7.18 & 3.80 & 4 & 3 & 54 & 39 & 5 & 7 & 54 & 34 \\
\hline 11 & 7.45 & 9.44 & 5.86 & 8 & 9 & 58 & 26 & 18 & 15 & 53 & 14 \\
\hline 12 & 4.24 & 7.16 & 2.98 & 0 & 1 & 37 & 61 & 2 & 6 & 64 & 28 \\
\hline 13 & 3.91 & 6.72 & 2.65 & 2 & 1 & 25 & 72 & 16 & 12 & 54 & 17 \\
\hline 14 & 4.07 & 8.02 & 2.21 & 0 & 0 & 14 & 86 & 2 & 4 & 50 & 45 \\
\hline 15 & 8.06 & 10.02 & 4.69 & 3 & 3 & 60 & 33 & 36 & 17 & 44 & 3 \\
\hline 16 & 6.15 & 7.63 & 3.85 & 5 & 4 & 58 & 33 & 21 & 17 & 51 & 11 \\
\hline 17 & 6.09 & 7.35 & 3.32 & 1 & 1 & 72 & 26 & 31 & 21 & 41 & 7 \\
\hline 18 & 4.15 & 6.33 & 3.35 & 3 & 3 & 57 & 37 & 7 & 5 & 61 & 27 \\
\hline 19 & 5.16 & 9.34 & 3.25 & 0 & 0 & 18 & 82 & 25 & 21 & 47 & 7 \\
\hline 20 & 4.57 & 6.88 & 3.09 & 3 & 3 & 43 & 51 & 6 & 7 & 60 & 27 \\
\hline 21 & 7.47 & 9.21 & 3.64 & 1 & 1 & 62 & 37 & 30 & 19 & 47 & 5 \\
\hline 22 & 6.47 & 9.12 & 3.32 & 1 & 1 & 40 & 58 & 10 & 13 & 54 & 23 \\
\hline 23 & 8.36 & 13.34 & 4.26 & 0 & 0 & 8 & 92 & 36 & 17 & 42 & 5 \\
\hline 24 & 6.88 & 6.08 & 3.86 & 4 & 0 & 52 & 44 & 4 & 0 & 36 & 60 \\
\hline 25 & 5.83 & 8.70 & 5.51 & 1 & 3 & 74 & 22 & 30 & 20 & 39 & 11 \\
\hline 26 & 6.72 & 9.69 & 5.01 & 2 & 2 & 71 & 25 & 17 & 8 & 38 & 38 \\
\hline 27 & 6.51 & 9.06 & 8.35 & 5 & 19 & 42 & 34 & 15 & 10 & 58 & 17 \\
\hline 28 & 6.83 & 12.25 & 11.49 & 0 & 10 & 76 & 14 & 5 & 52 & 19 & 24 \\
\hline 29 & 10.01 & 14.74 & 10.17 & 4 & 4 & 56 & 36 & 15 & 7 & 67 & 11 \\
\hline 30 & 12.84 & 16.62 & 12.66 & 17 & 4 & 63 & 16 & 13 & 19 & 55 & 13 \\
\hline 31 & 7.80 & 11.19 & 8.47 & 0 & 0 & 100 & 0 & 0 & 0 & 100 & 0 \\
\hline 32 & 10.70 & 14.73 & 10.22 & 9 & 4 & 44 & 43 & 10 & 5 & 77 & 8 \\
\hline 33 & 12.25 & 18.06 & 9.94 & 1 & 1 & 47 & 52 & 17 & 15 & 66 & 2 \\
\hline 34 & 14.50 & 17.37 & 19.97 & 10 & 10 & 60 & 20 & 13 & 12 & 57 & 17 \\
\hline 35 & 14.97 & 21.54 & 13.60 & 1 & 8 & 49 & 42 & 65 & 7 & 26 & 1 \\
\hline 36 & 13.58 & 20.12 & 11.20 & 0 & 0 & 46 & 54 & 97 & 1 & 3 & 0 \\
\hline 37 & 13.16 & 18.80 & 10.53 & 0 & 0 & 18 & 81 & 87 & 5 & 7 & 1 \\
\hline 38 & 13.46 & 19.98 & 10.63 & 0 & 0 & 8 & 92 & 96 & 1 & 3 & 0 \\
\hline 39 & 12.19 & 19.37 & 10.52 & 0 & 0 & 34 & 66 & 74 & 13 & 12 & 2 \\
\hline 40 & 8.59 & 16.67 & 13.70 & 0 & 1 & 75 & 24 & 15 & 16 & 56 & 12 \\
\hline 41 & 6.67 & 7.78 & 3.35 & 0 & 0 & 77 & 22 & 47 & 17 & 33 & 3 \\
\hline 42 & 5.31 & 7.66 & 4.61 & 0 & 6 & 74 & 20 & 29 & 13 & 46 & 11 \\
\hline 43 & 5.07 & 7.48 & 4.03 & 1 & 2 & 63 & 33 & 19 & 13 & 46 & 22 \\
\hline 44 & 4.92 & 8.49 & 5.05 & 0 & 0 & 68 & 32 & 36 & 16 & 44 & 4 \\
\hline 45 & 13.92 & 19.98 & 11.59 & 0 & 1 & 36 & 63 & 81 & 7 & 11 & 1 \\
\hline 46 & 7.93 & 10.96 & 5.36 & 0 & 0 & 25 & 75 & 0 & 1 & 92 & 7 \\
\hline 47 & 7.69 & 15.07 & 11.59 & 0 & 0 & 70 & 30 & 28 & 24 & 44 & 5 \\
\hline 48 & 7.17 & 10.53 & 14.05 & 1 & 0 & 54 & 45 & 3 & 1 & 37 & 59 \\
\hline 49 & 10.26 & 11.34 & 14.44 & 16 & 5 & 77 & 3 & 29 & 9 & 59 & 3 \\
\hline 50 & 10.59 & 13.41 & 13.59 & 13 & 15 & 52 & 21 & 30 & 10 & 57 & 4 \\
\hline 51 & 9.12 & 14.61 & 12.30 & 1 & 6 & 52 & 41 & 18 & 18 & 48 & 17 \\
\hline 52 & 8.23 & 14.91 & 9.67 & 1 & 2 & 50 & 47 & 45 & 21 & 28 & 6 \\
\hline 53 & 8.20 & 14.29 & 12.99 & 2 & 3 & 55 & 40 & 32 & 16 & 49 & 13 \\
\hline 54 & 8.29 & 14.88 & 11.59 & 1 & 4 & 65 & 30 & 27 & 24 & 43 & 7 \\
\hline 55 & 10.22 & 16.83 & 14.43 & 1 & 11 & 69 & 20 & 31 & 29 & 36 & 4 \\
\hline 56 & 10.00 & 15.23 & 10.43 & 1 & 4 & 48 & 46 & 8 & 14 & 58 & 20 \\
\hline 57 & 9.10 & 15.24 & 8.52 & 3 & 1 & 48 & 48 & 9 & 21 & 68 & 2 \\
\hline 58 & 10.30 & 14.43 & 12.16 & 10 & 22 & 26 & 6 & 56 & 23 & 19 & 1 \\
\hline 59 & 11.65 & 17.85 & 15.73 & 3 & 6 & 82 & 9 & 62 & 16 & 20 & 2 \\
\hline 60 & 10.57 & 14.98 & 12.64 & 15 & 35 & 41 & 8 & 67 & 15 & 17 & 1 \\
\hline 61 & 11.22 & 14.90 & 14.71 & 23 & 33 & 39 & 5 & 59 & 20 & 19 & 3 \\
\hline 62 & 11.34 & 15.68 & 12.17 & 7 & 35 & 52 & 6 & 69 & 21 & 9 & 0 \\
\hline 63 & 16.13 & 21.58 & 20.12 & 6 & 10 & 53 & 30 & 26 & 15 & 48 & 12 \\
\hline 64 & 11.25 & 19.68 & 11.14 & 0 & 0 & 67 & 33 & 61 & 16 & 20 & 3 \\
\hline 65 & 14.64 & 21.97 & 13.50 & 1 & 3 & 59 & 37 & 68 & 10 & 20 & 3 \\
\hline 66 & 14.23 & 18.73 & 16.22 & 9 & 32 & 50 & 9 & 44 & 12 & 43 & 1 \\
\hline 67 & 12.44 & 17.54 & 13.87 & 3 & 28 & 56 & 13 & 50 & 18 & 31 & 2 \\
\hline 68 & 13.92 & 18.74 & 13.08 & 9 & 15 & 67 & 10 & 83 & 10 & 7 & 0 \\
\hline 69 & 12.89 & 16.72 & 14.50 & 11 & 41 & 46 & 2 & 70 & 13 & 17 & 0 \\
\hline 70 & 12.35 & 16.61 & 12.73 & 5 & 23 & 67 & 5 & 83 & 7 & 9 & 1 \\
\hline 71 & 12.30 & 18.28 & 12.82 & 1 & 10 & 68 & 21 & 48 & 26 & 23 & 3 \\
\hline 72 & 10.62 & 17.96 & 11.85 & 0 & 1 & 68 & 31 & 46 & 28 & 24 & 1 \\
\hline 73 & 14.06 & 18.36 & 18.52 & 7 & 7 & 57 & 29 & 24 & 19 & 43 & 15 \\
\hline
\end{tabular}


Table 4 (continued)

\begin{tabular}{|c|c|c|c|c|c|c|c|c|c|c|c|}
\hline \multirow[t]{2}{*}{ No. } & \multicolumn{3}{|c|}{ Mean GPP $\left(\mathrm{MgC} \mathrm{ha}^{-1} \mathrm{y}^{-1}\right)$} & \multicolumn{4}{|c|}{ Absolute agreement } & \multicolumn{4}{|c|}{ Spatial variation agreement } \\
\hline & MODIS & SPOT & 3PGS & $\% 3$ agree & $\% 2$ agree & $\% 1$ agree & \%0 agree & \%3 agree & $\% 2$ agree & \%1 agree & $\% 0$ agree \\
\hline 74 & 14.76 & 21.96 & 14.95 & 1 & 8 & 70 & 21 & 54 & 12 & 32 & 2 \\
\hline 75 & 19.17 & 23.54 & 19.45 & 9 & 8 & 52 & 31 & 13 & 19 & 52 & 16 \\
\hline 76 & 18.63 & 18.24 & 24.71 & 21 & 13 & 42 & 24 & 21 & 13 & 51 & 15 \\
\hline 77 & 8.71 & 11.48 & 6.73 & 8 & 9 & 45 & 39 & 10 & 7 & 72 & 12 \\
\hline 78 & 12.90 & 18.90 & 6.64 & 2 & 1 & 19 & 78 & 34 & 21 & 38 & 7 \\
\hline 79 & 7.48 & 13.79 & 3.53 & 0 & 0 & 6 & 93 & 30 & 20 & 43 & 6 \\
\hline 80 & 4.24 & 7.39 & 3.25 & 2 & 2 & 39 & 57 & 17 & 16 & 50 & 17 \\
\hline 81 & 4.43 & 7.09 & 1.61 & 0 & 2 & 10 & 88 & 7 & 5 & 32 & 56 \\
\hline 82 & 9.96 & 13.66 & 11.25 & 9 & 25 & 61 & 6 & 68 & 12 & 20 & 1 \\
\hline 83 & 10.27 & 14.33 & 12.18 & 13 & 18 & 53 & 17 & 39 & 22 & 36 & 3 \\
\hline 84 & 13.73 & 18.23 & 14.20 & 4 & 7 & 61 & 28 & 11 & 19 & 51 & 19 \\
\hline
\end{tabular}

The shaded columns match the color breakdown in Figs. 4 and 5. The 10 most forested ecoregions are shaded darker gray in the table.

for 3-PGS (9.78), and MODIS (9.92) but significantly higher for SPOT (14.17). As ecoregions become less forested, there is a general trend toward lower productivity reflected in all model predictions.

In addition to the mean difference between the three models, we also consider the spatial variation in GPP (also shown in Table 4). To do this, the mean ecoregion GPP was estimated and used to normalize the variation in GPP within each ecoregion. These values were then compared across the three models, as shown in Fig. 4. The results indicate that overall, the Pacific Northwest region has poor model agreement in the degree of spatial variation predicted by the three GPP models. Key areas of similarity include the small areas of Western Cordillera in Puget Sound, small pockets in the Eastern Cascades and the along the Coast Mountains. Further south, the forests in the Californian Coastal Sage, Chaparral, and Oak Woodlands have highly variable GPP estimated across models relative to their ecoregion mean, with only some small areas of the forests in the Sierra Nevada in agreement. In contrast, the forests in the South-eastern Plains, Ozark Highlands and the South Central Plains are all in very good agreement with all models predicting the same degree of spatial variation in GPP across these ecoregions. Further north, again the Central Appalachians, Northern Appalachian Atlantic Maritime Highlands and Maine/New Brunswick Plains and Hills are all in excellent agreement across all models. The coastal forests, however, including the Middle Atlantic Coastal Plain and Southern Coastal Plain, are in poor

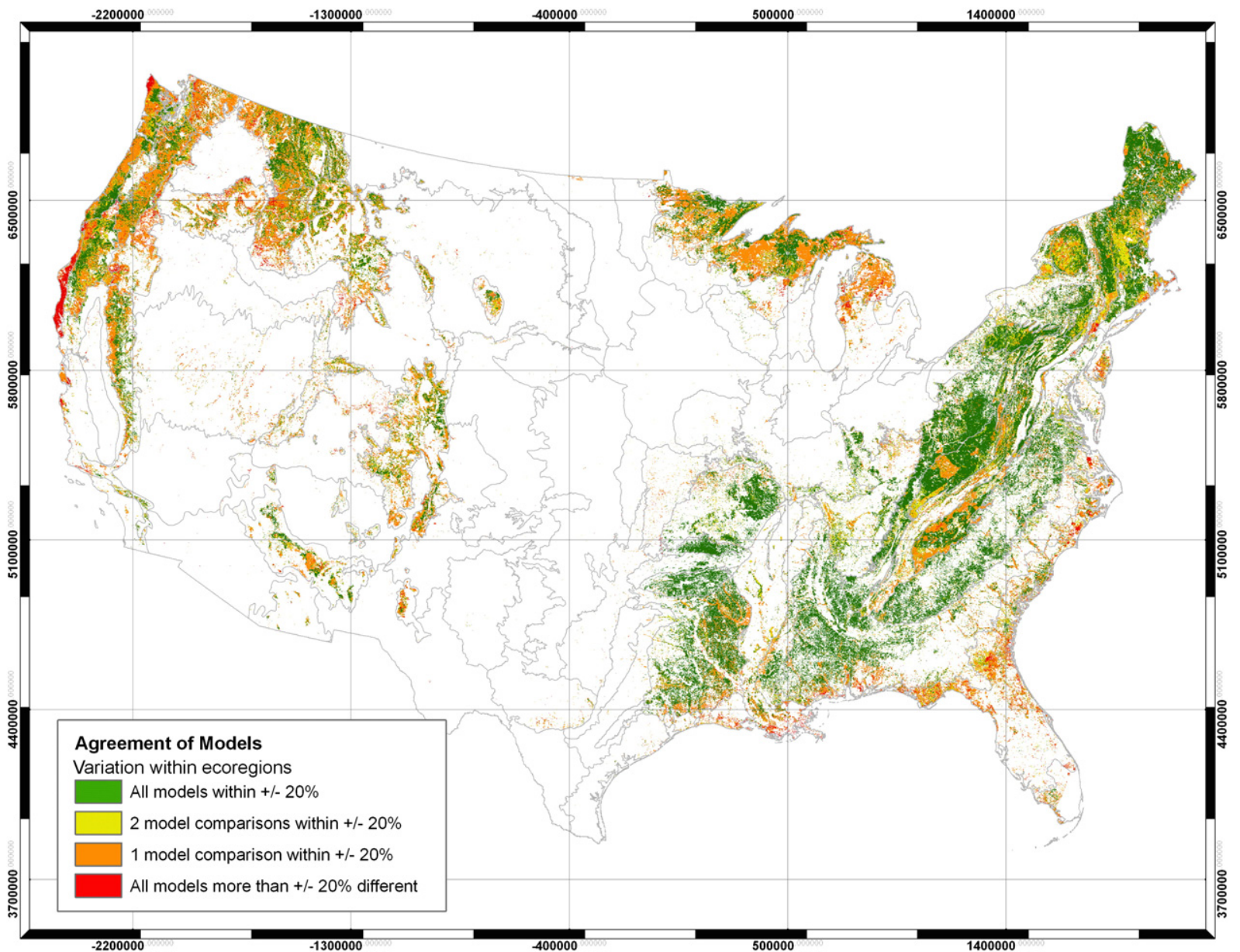

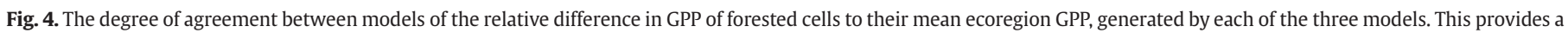
basis for comparing variation predicted within individual ecoregions by the 3 models. 


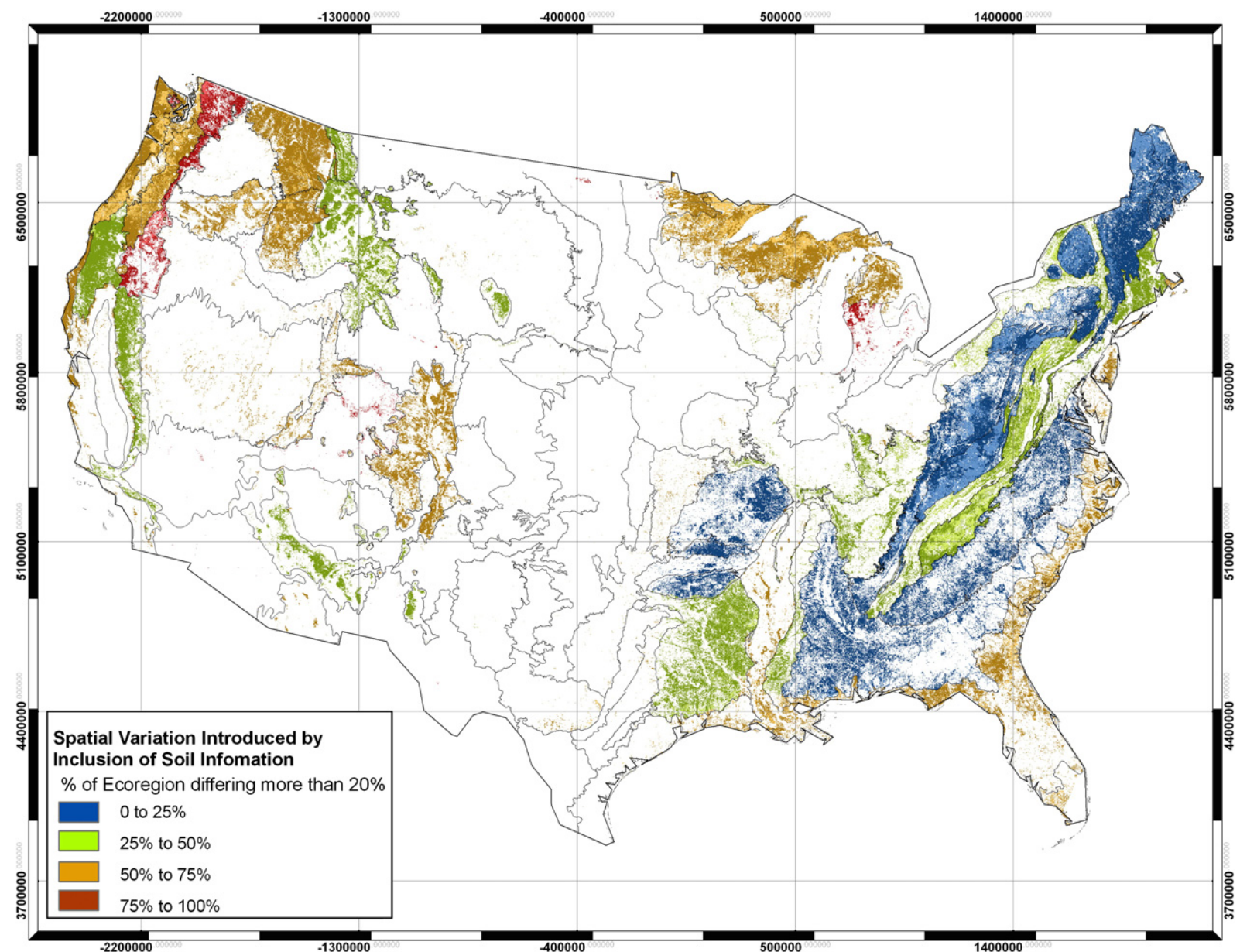

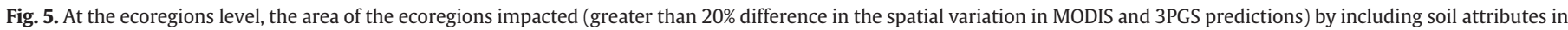

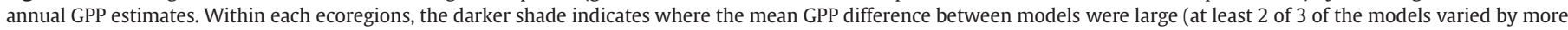

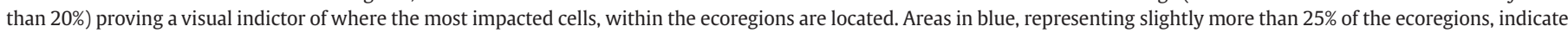

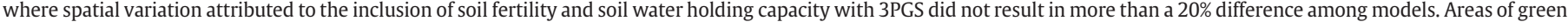

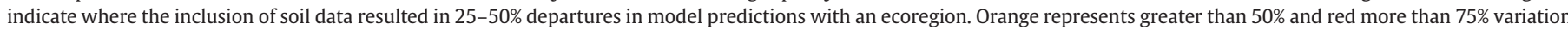

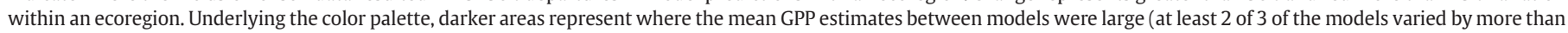
$20 \%$, providing a visual indicator of where most cells were located.

agreement with all models, or with only 1 set of models predicting the same degree of variation in GPP.

The implications of introducing increasing data requirements for the models are summarized in Fig. 5 at the ecoregion level.

\subsection{Impact of soil fertility}

Errors in estimating soil fertility, which in turn affect $\alpha$, have the most effect where soil water is not limiting, as is generally the case (but certainly not always) for areas east of the Mississippi River. In contrast, the areas where lack of information on soil water holding capacity causes overestimation of GPP is in the arid portions of the western part of the country, including the fringes of forests along interior valleys and on the eastern slopes of major mountain ranges. The results presented in Fig. 5, confirm this and provide additional insights. Predictions of GPP by the three models are relatively consistent in the Northeast US, implying that model assumptions on the value of $\alpha$, are similar to that assumed by the SPOT model (i.e. $1.1 \mathrm{gC} \mathrm{MJ}^{-1}$ APAR).

In the southern US, however, model predictions of GPP differed by at least $20 \%$ (shown in dark brown) within $75 \%$ of the individual ecoregions, e.g., ecoregion 63: Middle Atlantic Coastal Plains). In such areas attempts to account for variation in soil properties as they affect photosynthetic capacity will cause large variation in estimates of GPP compared with models that lack this specificity. Other areas with similar levels of disagreement are located in the 49: Northern Minnesota Wetlands and 50: Northern Lakes and Forests ecoregions.

\subsection{Impact of soil water}

Moving westward, soil water restrictions on forest growth become more significant as described in previous work. A sensitivity analyses varying soil water storage from 50 to $400 \mathrm{~mm}$ clearly delineated the most drought-prone areas (ref. Fig. 2 in Nightingale et al., 2007) which mimic to some extent the large areas of model disagreement in Fig. 4. These results provide additional evidence of contrasting effects in different western ecoregions. In the 77: North Cascades and 9: Eastern Cascades Slopes and Foothills level III ecoregions there is major model disagreement, with all model predictions of annual GPP disagreeing by more than $20 \%$. In addition, all three models over the majority of the ecoregion (70-100\%), predict different spatial variability These results indicate that GPP predictions in these areas needs to be applied with caution, and that accurate information on soil water holding capacity, although difficult to obtain, may be critical. By comparison, further south in ecoregion 78: Klamath Mountains and the 5: Sierra Nevada, there is still relatively little model agreement (all three models disagree in GPP predictions by more than $20 \%$, as denoted by a darker green color) however the spatial variability predicted by the models is less variable between models, with $25-50 \%$ of the area of the ecoregion varying model predictions of the spatial variability of GPP. 


\section{Discussion}

Satellites orbiting the Earth since the 1960s have provided a means of estimating seasonal and interannual variation in vegetation cover (Skole \& Tucker, 1993; Mildrexler et al., 2007). For all three models compared in this paper, vegetation dynamics are indispensible for estimating the seasonal and interannual changes in fPAR at a range of spatial and temporal scales. When combined with quantitative estimates of photosythetically active radiation (PAR), and estimates of the photosynthetic capacity, a common basis for estimating GPP is provided. The inclusion of seasonal drought and sub-optimal temperatures reduce GPP substantially, associated with a reduction in photosynthetic activity. The subsequent inclusion of soil fertility and soil water holding capacity, in theory, should lead to more accurate assessment of GPP, and ultimately NPP (Running, 1994; Running et al., 2004). The challenge is in obtaining the required information across broad areas (Coops \& Waring, 2001). Soils are inherently variable and soil maps are often inaccurate. The scale of most regional and continental soil maps range from 1:500 000 to $1: 1000000$, resulting in significant variation within areas that are denoted as relatively homogeneous (Landsberg et al., 2003).

\subsection{MODIS model verification}

Verification of all of these GPP modeling approaches is underway. The MODIS MOD 17 GPP product has undergone the most testing, and is continually being updated in response to improvements in climatic data, fPAR smoothing, gap-filling, and land cover definition. Turner et al. (2003) compared MODIS GPP with GPP estimates based on model-scaled ground observations at temperate hardwood and boreal conifer forested sites. At the hardwood forest site, the summertime MODIS GPP was generally lower than the measured GPP values, and at boreal forest site, GPP was generally higher than those derived from eddy-co-variance analyses. Turner et al. (2005) evaluated MODIS production estimates across six sites with widely varying climates, land use, and vegetation physiognomy. No consistent over- or under prediction of MODIS GPP were reported. Closest agreement occurred at the temperate deciduous forest, arctic tundra, and boreal forest sites, whereas modeled GPP for desert grassland and at the dry coniferous forest sites was overestimated.

More recently, Gebremichael and Barross (2006) evaluated MODIS GPP estimates of tropical ecosystems and found a positive bias in predictions for the mixed forest biome and a negative bias for the open scrublands, attributed in part to deficiencies in the global meteorology data. In a comprehensive evaluation of the MODIS GPP product, Heinsch et al. (2006) found that GPP was overestimated by an average $20-30 \%$ at most sites relative to the tower-based ecosystems. MODIS substantially underestimated (19-40\%) GPP at the most productive site evaluated (the Duke Forest site, North Carolina). The cause for these errors were attributed to underestimation of vapor pressure deficit from inadequate coverage provided in the global meteorological data and from not accounting for deficits in soil moisture at water-limited sites in the U.S. (e.g., Baldocchi et al., 2001; Turner et al., 2003; Heinsch et al., 2006).

\subsection{SPOT C-Fix model verification}

Across a range of sites in Italy, Maselli et al. (2006) found the SPOT (C-Fix VGT)-derived estimates of GPP were in general agreement with measurements acquired at sites with broadleaf deciduous forests and were less accurate at sites with needleleaf evergreens. The accuracy of annual GPP estimates was better than monthly or seasonal comparisons, for which differences in photosynthesis were accentuated beyond true values (Maselli et al., 2006). Recently Verstraeten et al. (2006) developed a suite of algorithms to be coupled with C-Fix to allow the model to utilize information on soil water availability. The coupled model, applied at a number of flux tower sites across Europe, predicted GPP more accurately than the standard C-FIX model $\left(R^{2}\right.$ increased slightly from 0.59 to 0.65 ) reducing ecosystem production by $42 \%$ compared to the standard C-Fix measurements. Respiration has also been changed to be a function of GPP (Lu et al., 2004).

\subsection{3-PGS model verification}

Similarly, the 3PG suite of models have been used extensively to model the productivity of a wide range of forest types across North America including ponderosa pine (Pinus ponderosa) (Law et al., 2000); lodgepole pine (Pinus contorta) (Hall et al., 2006); Loblolly pine (Pinus taeda) (Landsberg et al., 2000); and jack pine (Pinus banksiana) (Peng et al., 2002). Results indicate the model predictions are accurate when compared to site index and forest inventory data and in addition, although the water balance in imprecise, it is generally effective in capturing regional trends at the monthly time scale (Nightingale et al., 2008).

Not all of these differences can be attributed to the representation of process within the models, or to the degree that soil properties are assessed. In the case of the 3-PGS and MODIS models, where both use the same climate and fPAR data, the presence or absence of soil data probably contribute significantly to variation observed in some ecoregions. In the case of the SPOT GPP predictions, we were limited to accepting model predictions as given, recognizing that the climatic drivers differed from those used in the other models. As a result, some differences between the SPOT model and the other two models may reflect the different climate (and fPAR) datasets, rather than the models themselves. In the case of climate variations and their impact of prediction of GPP we believe these differences to be relatively minor (Zhao et al. (2006) for detailed discussion on impact of climate difference on GPP prediction). Similarly the impact of differences is also likely to be low as fPAR is most accurately determined at low values, equivalent to LAI values $<3.0$. When LAI $>5.0$, fPAR is less accurately assessed, however errors are reduced because beyond that density of cover $>95 \%$ of visible light is intercepted. Our approach of comparing the normalized spatial variation of GPP within each ecoregion attempts to minimize this effect by comparing the GPP relative to the ecoregion mean and not simply to the absolute differences in GPP. We believe that attempts to recognize differences in soil fertility in the 3-PGS model contribute to most of the variation in GPP predictions within ecoregions.

In summary our results show that where soils are uniform, and considered of low fertility, little differences should be expected among model predictions. Similarly differences in soil fertility on model predictions will have the most effect where soil water is not limiting.. The results indicate that for areas east of the Mississippi River impacts of soil fertility are minimal with GPP predictions by all three models being relatively consistent in the Northeast US. Where soil fertility is assumed to vary, up to a 2-fold difference in estimates of GPP. This is most evident in the south eastern US such as the Atlantic Coastal Plains.

In areas where soil water drought is prevalent some at least 1 month of the year, and there is a lack of soil water information, overestimation of GPP will occur. As a result this impact is most evident in the arid portions of the western part of the country. There is major disagreement in both the magnitude, and spatial variation in model predictions of GPP, in the North and Eastern Cascades. Further southwest, differences are apparent in the magnitude, but not the spatial variation in GPP predictions.

\section{Conclusion}

We believe that the types of comparisons presented in this paper effectively identify areas where the most uncertainty exists, and where additional research could improve regional and global 
estimates of GPP, as well as other ecosystem properties. In addition, from these types of model comparisons, finding areas where models agree, helps one understand the extent that variation in climatic conditions are modest or extreme within an ecoregion. Across broad areas, we also conclude that it is reasonable to use less datademanding models rather than assume that soil properties are accurately mapped and interpreted.

\section{Acknowledgments}

This study was supported by the National Aeronautics and Space Administration (NASA Grant NNG04GK26G) as part of the Biodiversity and Ecological Forecasting program, and the University of British Columbia (UBC). Meteorological data were provided by the NTSG group at the University of Montana. We are particularly grateful to Maosheng Zhao for providing interpolation code to allow us to utilize these datasets. In addition we thank the scientists in GMAO, especially Mahendra K. Karki, for providing consistent GEOS-4 GMAO data.

\section{References}

Baldocchi, D., Falge, E., Gu, L., Olson, R., Hollinger, D., Running, S. W., et al. (2001). FLUXNET: A new tool to study the temporal and spatial variability of ecosystemScale carbon dioxide, water vapor, and energy flux densities. Bulletin of the American Meteorological Society, 82, 2415-2434.

Commission for Environmental Cooperation (CEC). (1997). Ecological Regions of North America: Toward a Common Perspective. Commission for Environmental Cooperation. Montreal, Quebec, Canada, 71pp. (Report and Map (scale 1:12,500,000)).

Coops, N. C., \& Waring, R. H. (2001). Estimating maximum potential site productivity and site water stress of the Eastern Siskiyous using 3-PGS. Canadian Journal of Forest Research, 31, 143-154.

Coops, N. C., Waring, R. H., \& Landsberg, J. J. (1998). Assessing forest productivity in Australia and New Zealand using a physiologically-based model driven with averaged monthly weather data and satellite derived estimates of canopy photosynthetic capacity. Forest Ecology and Management, 104, 113-127.

DAO (2002). Data Assimilation Office (DAO) Algorithm Theoretical Basis Document (ATBD). Data Assimilation Office Greenbelt, MD: Goddard Space Flight Center.

Gebremichael, M., \& Barross, A. P. (2006). Evaluation of MODIS gross primary productivity (GPP) in tropical monsoon regions. Remote Sensing of Environment, 100, 150-166.

Hall, R. J., Raulier, F., Price, D. T., Arsenault, E., Bernier, P. Y., Case, B. S., et al. (2006). Integrating remote sensing and climate data with process-based models to map forest productivity within west-central Alberta's boreal forest: Ecoleap-West. Forestry Chronicle, 82, 159-178.

Hansen, M. C., DeFries, R. S., Townshend, J. R. G., \& Sohlberg, R. (2000). Global land cover classification at $1 \mathrm{~km}$ spatial resolution using a classification tree approach. International Journal of Remote Sensing, 21, 1331-1364.

Hargrove, W., \& Hoffman, F. (2004). Potential of multivariate quantitative methods for delineation and visualization of ecoregions. Environmental Management, 34, S39-S60.

Heinsch, F. A., Zhao, M., Running, S. W., Kimball, J. S., Nemani, R. R., Davis, K. J., et al. (2006). Evaluation of remote sensing based terrestrial productivity from MODIS using regional tower eddy flux network observations. IEEE Transactions on Geoscience and Remote Sensing, 44, 1908-1925.

Landsberg, J. J. (2003). Modelling forest ecosystems: State-of-the-art, challenges and future directions. Canadian Journal of Forest Research, 33, 385-397.

Landsberg, J. J., Johnsen, K. H., Albaugh, T. K., Allen, A. L., \& McKeand, S. E. (2000). Applying 3-PG, a simple process-based model designed to produce practical results, to data from Loblollly pine experiments. Forest Science, 47, 43-51.

Landsberg, J. J., \& Waring, R. H. (1997). A generalized model of forest productivity using simplified concepts of radiation-use efficiency, carbon balance and partitioning. Forest Ecology and Management, 95, 209-228.
Landsberg, J. J., Waring, R. H., \& Coops, N. C. (2003). Performance of the forest productivity model 3-PG applied to a wide range of forest types. Forest Ecology and Management, 172, 199-214.

Law, B. E., Williams, M., Anthoni, P., Baldocchi, D., \& Unsworth, M. (2000). Measuring and modelling seasonal variation of carbon dioxide and water vapour exchange of a Pinus ponderosa forest subject to soil water deficit. Global Change Biology, 6, 613-630.

Lu, L., Li, X., Veroustraete, F., \& Dong, Q. H. (2004). Estimation of NPP in western China using remote sensing and the C-Fix model. IEEE International Geoscience and Remote Sensing Symposium. (IGARSS '04)Proceedings, Vol. 1. (pp. 12-15).

Maselli, F., Barbati, A., Chiesi, M., Chirici, G., \& Corona, P. (2006). Use of remotely sensed and ancillary data for estimating forest gross primary productivity in Italy. Remote Sensing of Environment, 100, 563-575.

Mc Cree, K. (1972). Test of current definitions of photosynthetically active radiation against leaf photosynthesis data. Agricultural Meteorology, 10, 442-453.

Mildrexler, D. J., Zhao, M., Heinsch, F. A., \& Running, S. W. (2007). A new satellite based methodology for continental scale disturbance detection. Ecological Applications, $17,235-250$.

Myneni, R. B., Hoffman, S., Knyazikhin, Y., Privette, J. L., Glassy, J., Tian, Y., et al. (2002). Global products of vegetation leaf area and fraction absorbed PAR from year one of MODIS data. Remote Sensing of Environment, 83, 214-231.

Nightingale, J. M. Coops, N. C., Waring, R. H., \& Hargrove, W. W. (2007) Comparison of MODIS Gross Primary Production estimates for forests across the U.S.A. with those generated by a simple process model, 3-PGS. Remote Sensing of Environment, 109 500-509.

Nightingale, J. M., Fan, W., Coops, N. C., \& Waring, R. H. (2008). Predicting tree diversity across the USA as a function of modeled gross primary production. Ecological Applications, 18, 93-108.

Nightingale, J. M., Phinn, S. R., \& Held, A. A. (2004). Ecosystem process models at multiple scales for mapping tropical forest productivity. Progress in Physical Geography, 28, 241-281.

Peng, C. H., Liu, J. X., Dang, Q. L., Apps, M. J., \& Jiang, H. (2002). TRIPLEX: A generic hybrid model for predicting forest growth and carbon and nitrogen dynamics. Ecological Modelling, 153, 109-130.

Running, S. W. (1994). Testing Forest-BGC ecosystem process simulations across a climate gradient in Oregon. Ecological Applications, 4, 238-247.

Running, S. W., Nemani, R. R., Heinsch, F. A., Zhao, M., Reeves, M., \& Jolly, M. (2004). A continuous satellite-derived measure of global terrestrial primary productivity: Future science and applications. Bioscience, 56, 547-560.

Sabbe, H., \& Veroustraete, F. (2000). Demonstration of a standard net primary productivity product for the SPOT 4-VEGETATION instrument. Belgium: VITO.

SAS (2004). SAS Version 9.1.3. help and documentation. Cary, NC: SAS Institute.

Skole, D., \& Tucker, C. (1993). Tropical deforestation and habitat fragmentation in the Amazon: Satellite data from 1978 to 1988. Science, 260, 1905-1909.

Turner, D. P., Ritts, W. D., Cohen, W. B., Gower, S. T., Zhao, M., Running, S. W., et al. (2003). Scaling gross primary production (GPP) over boreal and deciduous fores landscapes in support of MODIS GPP product validation. Remote Sensing of Environment, 88, 256-270.

Turner, D. P., Ritts, W. D., Cohen, W. B., Maeirsperger, T. K., Gower, S. T., Kirschbaum, A. A., et al. (2005). Site-level evaluation of satellite-based global terrestrial gross primary production and net primary production monitoring. Global Change Biology, 11 666-684.

Veroustraete, F., Sabbe, H., \& Eerens, H. (2002). Estimation of carbon mass fluxes over Europe using the C-Fix model and Euroflux data. Remote Sensing of Environment, 83, 376-399.

Veroustraete, F., Sabbe, H., Rasse, D., \& Bertels, L. (2004). Carbon mass fluxes of forests in Belgium determined with low resolution optical sensors. International Journal of Remote Sensing, 25, 769-792.

Verstraeten, W. W., Veroustraete, F., \& Feyen, J. (2006). On temperature and water limitation of net ecosystem productivity: Implementation in the C-Fix model. Ecological Modelling, 199, 4-22.

Waring, R. H., Landsberg, J. J., \& Williams, M. (1998). Net primary production of forests: A constant fraction of gross primary production? Tree Physiology, 18, 129-134.

Zhao, M., Running, S. W., \& Nemani, R. R. (2006). Sensitivity of moderate resolution imaging spectroradiometer (MODIS) terrestrial primary production to the accuracy of meteorological reanalyses. Journal of Geophysical Research, 111, G01002. doi:10.1029/2004JG000004. 